\title{
Induced Resistance to Fusarium wilt (Fusarium oxysporum) in Tomato using Plant Growth Activator, Acibenzolar-S-methyl
}

\author{
Animashaun, B. 0.1, Popoola, A. R.1 , Enikuomehin, 0. A. ${ }^{1}$, Aiyelaagbe, I. 0. \\ 0.2 and Imonmion, J. E.1 \\ ${ }^{1}$ Department of Crop Protection, Federal University of Agriculture, Abeokuta. Nigeria. \\ ${ }^{2}$ Department of Horticulture, Federal University of Agriculture, Abeokuta. Nigeria.
}

\section{Abstract}

(Received: 19:03:2017; Accepted: 14:04:2017)

\begin{abstract}
Acibenzolar-s-methyl (ASM) is a plant systemic-acquired resistance (SAR) elicitor that belongs to the benzothiadiazole group and it induces SAR in tomato plant (Solanum lycopersicum L.) against Fusarium oxysporum f. sp. Iycopercisi (FOL), the causative organism of vascular wilt of tomato. It is a good substitute to chemical fungicides which often resulted in environmental damage and increased pathogen resistance. Two tomato accessions FUNAABTO 0168 (Accession I) and FUNAABTO 0178 (Accession II) were used. This study assessed the resistance of two accessions of ASM-treated tomato to FOL, identified the most effective method of ASM application and examined the influence of applied ASM on yield indices of the accessions. Tomato plants not treated with ASM (Nn) had the highest disease severity at $5^{\text {th }}$ to $8^{\text {th }}$ week after transplanting with corresponding value of 1.33, 2.00, 2.17 and 3.33 in Accession I and 1.00, 1.33, 1.50 and 1.67 in II. Primed and sprayed (Ps) method was the most effective of ASM application with least severity (0.00) and also had the highest yield in Accession I (3.35 ton/ha) and II (4.14 ton/ha), while tomato plant untreated ( $\mathrm{Nn}$ ) had the least yield in Accession I (2.16 ton/ha) and II (1.23 ton/ha) respectively. It is recommended that tomato seeds be first primed in ASM followed by spraying of seedlings with ASM at transplant to significantly reduce incidence and severity of Fusarium wilt and increase yield of tomato fruits.
\end{abstract}

Keywords: Acibenzolar-S-methyl, SAR, FUNAABTO, tomato, wilt

Correspondence: odubanwobolaji@yahoo.com

\section{Introduction}

Tomato (Solanum lycopersicum L.) was native to tropical America, but grown all over the world (Arah et. al., 2015). Tomatoes production accounts for about 4.8 million hectares of harvested land area globally with an estimated production of 162 million tonnes (FAOSTAT, 2014). China leads world tomato production with about 50 million tonnes followed by India with 17.5 million tonnes (FAOSTAT, 2014). In Africa, total tomato production for 2012 was 17.938 million tons with Egypt leading the continent with 8.625 million tonnes, followed by Nigeria with 1.56 million tonnes (Arah et. al., 2015).

Tomato production can serve as a source of income for most rural and peri-urban producers in most developing countries. The tomato industry has been identified as an area that has the ability for poverty reduction because of its potential for growth and employment creation (Anang et. al., 2013). Tomato has become an important cash and industrial crop in many parts of the world (Ayandiji et. al., 2011) not only because of its economic importance but also its nutritional value to human diet and subsequent importance in human health (Willcox et al., 2003). In Nigeria, the production of the crop has improved the livelihood of most rural and peri-urban farmers (Adenuga et. al., 2013).

Fusarium oxysporum $f$. sp. lycopersici (FOL) has become one of the most damaging pathogen wherever tomatoes are grown intensively because it grows endophytically and persists in infested soils (Agrios, 1997). 
Fusarium oxysporum f. sp. lycopersici is a known pathogen of tomato plant which is an economically important crop (Suárez-Estrella et. al., 2007). Tomato yield is significantly reduced by $F$. oxysporum f. sp. lycopersici infect the tomato plant at the growing stages. Most strains assigned to this species are saprophytic or non-pathogenic. However, plant pathogenic strains $F$. oxysporum causes destructive vascular wilt diseases on a wide variety of crops, often limiting crop production (Nelson et. al., 1983). Individual pathogenic strains have a high degree of host specificity within F. oxysporum; it is generally known as a species complex which is assigned to intraspecific groups including formae species (f. sp.) and other forms (Kistler, 2001).

Most infections originate from the population associated with infected tomato debris. Healthy plants can become infected by F. oxysporum if the soil in which they are growing is infested with the pathogen. As a soil inhabitant, F. oxysporum can survive extended periods in the absence of the host, mainly in the form of thick walled chlamydospores. Indeed, once an area becomes infected with $F$. oxysporum, it usually remains so indefinitely (Agrios, 1997).

The pathogen invades the vascular tissues, grows in the vascular bundles and inhibits water flow consequently causing wilting, ultimately leading to death of the plant (Davies, 1982). Wilt lead to an average yield loss of $50 \%$ in tomato. It reduces farmer's income and family intake of vitamin A. It constitutes serious threat to food security in Sub-Saharan Africa, especially in the coastal regions (Popoola et. al., 2012).

The frequent use of synthetic fungicides to tackle fungal wilt of tomato has often resulted in environmental damage and increased pathogen resistance (Ogzonen et al., 2001). Resistance of F. oxysporum f. sp. lycopersici to synthetic fungicides necessitates the use of alternative control method to wilt caused by the pathogen. Acibenzolar-S-methyl (ASM) has been developed as a potential Systemic Acquired Resistance (SAR) activator. Rather than being fungistatic or fungicidal, this compound induces resistance by activating the Systemic Acquired Resistance signal transduction pathway in several plant species (Görlach et al., 1996). Furthermore, efficacious dose is non-phytotoxic and the product is environmentally friendly.

Acibenzolar-S-methyl (ASM) has been developed as a potential Systemic Acquired
Resistance (SAR) activator. Rather than being fungistatic or fungicidal, this compound induces resistance by activating the Systemic Acquired Resistance signal transduction pathway in several plant species (Görlach et al., 1996).

Plants possess a range of active defence responses, which can be triggered by inducible resistance system and is known as systemic acquired resistance (SAR). Systemic acquired resistance (SAR) refers to a distinct signal transduction pathway that plays an important role in the ability of plants to defend themselves against pathogens and has proved effective against diverse pathogens including viruses, bacteria, and fungi (Ryals et. al., 1996).

The SAR signal transduction pathway appears to function as a potentiator or modulator of other disease resistance mechanisms. When Systemic Acquired Resistance is activated, a normally compatible plant-pathogen interaction (one in which disease is the normal outcome) can be converted into an incompatible one (Uknes et. al., 1992). Conversely, when the SAR pathway is incapacitated, a normally incompatible interaction becomes compatible (Delaney et. al., 1994). A number of biochemical and physiological changes have been associated with pathogen infection. These include cell death and the oxidative burst (Low and Merida, 1996), deposition of callose and lignin (Kauss, 1987), and the synthesis of phytoalexins and novel proteins (Dangl et al., 1996). SAR elicits the expression of a set of genes called SAR genes (Ward et al., 1991). Rather than reduce pathogen populations directly, crop resistance is induced by activating the SAR signal transduction pathway in several plant species (Görlach et. al., 1996).

The development of SAR is associated with various cellular defence responses. These include synthesis of pathogenesis-related (PR) proteins, phytoalexins, accumulation of active oxygen species (AOS), rapid alterations in cell walls, and enhanced activity of various defence-related enzymes (Ryals et. al., 1996). In recent studies, AOS were more fully explored as a mechanism for SAR. There is ample evidence indicating that AOS, particularly $\mathrm{H}_{2} \mathrm{O}_{2}$, perform several important functions in early defence responses to plant pathogens. These include direct antimicrobial action, lignin formation, phytoalexin production, and the triggering of SAR (Lamb and Dixon, 1997). Produced via an oxidative 
burst, AOS are under the control of enzymes such as NADPH oxidase and peroxidases (POXs) (Wojtaszek, 1997). POXs have been implicated in the hypersensitive response and the formation of papilla and polymerization of lignin from monomeric lignols (Nicholson and Hammerschmidt, 1992). Furthermore, POXs have been implicated in the crosslinking reactions of cell wall associated proteins such as hydroxyproline-rich or glycine-rich glycoproteins (Brisson et. al., 1994).

As a result of oxidative cross-linking reactions, cell walls may be strengthened and function as physical barriers against invading pathogens. Furthermore, AOS produced via an oxidative burst are also under control of antioxidant defences including the lowmolecular weight antioxidant enzymes, such as catalase, POX and superoxide dismutase (SOD), and non-enzymatic antioxidants such as ascorbate POX, glutathione-S-transferase (GST) and glutathione peroxidase (GPX) (Alscher et. al., 1997). These enzymes play a crucial role in the protection of the plant cell from oxidative damage at the sites of enhanced AOS generation (Kuzniak and Sklokowska, 2001).

The objective of this study was to induce Systemic Acquired Resistance (SAR) to Fusarium wilt in tomato by application of acibenzolar-S-methyl (ASM) and to assess the effects of this application on incidence and severity of Fusarium wilt, as well as on growth and yield of tomato.

\section{Materials and Methods}

Source of seeds and acibenzolar-S-methyl (ASM)

Two tomato accessions (FUNAABTO 0168 and FUNAABTO 0178) were obtained from FUNAAB/DFID Tomato Germplasm Collection Centre, COLPLANT, FUNAAB. Both accessions were moderately susceptible to Fusarium wilt and were products of hybridization for resistance to Fusarium wilt. This study is therefore a continuation of as existing project on tomato production. Acibenzolar-S-Methyl Pestanal ${ }^{\circledR}$ was sourced from SIGMA-ALDRICH Limited (Germany).

\section{Application of Acibenzolar-S-Methyl (ASM)}

A wettable granular formulation of Acibenzolar-S-methyl was weighed and dissolved in sterile distilled water at concentration of $25 \mathrm{ppm}$. A batch of the tomato seeds from the two accessions was soaked in the ASM solution (primed) for 24 hours while the other batch was not soaked in the ASM solution. Both batches were sown in nursery for four weeks. Four week-old primed and unprimed tomato seedlings were transplanted into inoculated $15 \mathrm{~kg}$ potted soil in the screen house. Some transplanted primed and unprimed tomato seedlings were sprayed with ASM solution; some were root dipped in ASM solution while some were not treated with ASM solution.

\section{Isolation and inoculation of pathogen}

Wilted tomato plants with yellow leaves were collected and taken to the laboratory for fungal isolation. Stems from wilted tomato plants were macerated with a sterile scalpel and surface sterilized using $1 \%$ $\mathrm{NaOCl}$. It was rinsed in three changes of sterile distilled water and dried on sterile filter paper. Segments from the stems were placed on PDA in Petri-dishes and incubated at room temperature for 4 days. Sub culturing of fungal isolates was done to obtain pure cultures of few fungal isolates that appeared on the plates. Preliminary identification was conducted using morphological appearance to identify $F$. oxysporum f. sp. lycopercisi. Further identification using characteristic taxonomic and morphological features for $F$. oxysporum f. sp. lycopercisi was conducted as contained in the work of Leslie et. al. (2006).

Inoculation with the isolated $\mathrm{F}$. oxysporum f. sp. lycopercisi was conducted on four week-old tomato seedlings. Conidial suspension was prepared from 7 day-old cultured fungus. Inoculation was conducted by applying the conidial suspension (adjusted to $10^{6}$ spores / $\mathrm{ml}$ with the aids of haemocytometer) to the soil in pot at rate of 1 $\mathrm{ml} /$ hole, while some pot with soil was not inoculated with the isolated F. oxysporum.

\section{Experimental site and nursery preparation}

The experiment was conducted in the screen-house of Tomato Research Project, Federal University of Agriculture, Abeokuta, Nigeria (FUNAAB). The Laboratory experiment was carried out in Tissue Culture Laboratory, Department of Crop of Protection, College of Plant Science and Crop Production, FUNAAB. Soil sterilization was done locally and was left to cool before bagging in sterile polythene bag for 2 weeks. The nursery was established and tomato seedlings were grown for 4 weeks before transplanting into $15 \mathrm{~kg}$ potted sterile soil in the screen-house. 
Experimental design and data analysis

The experiment was conducted in potted inoculated soil (15 kg each) in the screen-house and was laid out in a Completely Randomized Design with three replicates. The treatment consisted of two accessions; FUNAABTO 0168 and FUNAABTO 0178 (as Accession I and II, respectively) shown to be moderately susceptible to Fusarium wilt with the treatments shown in Table 1. Data were subjected to Analysis of Variance (ANOVA), using Statistical Analysis System (SAS) package, and the significantly different means of treatments were separated using the Duncan's Multiple Range Test $(p<0.05)$.

Table 1: Wilt severity scale

\begin{tabular}{ll}
\hline Score & Percent infection \\
\hline $\mathbf{0}$ & No Symptom, \\
$\mathbf{1}$ & $1-20 \%$ of leaves yellowed and wilted, \\
$\mathbf{2}$ & $21-40 \%$ of leaves yellowed and wilted; \\
$\mathbf{3}$ & $41-60 \%$ of leaves yellowed and wilted; \\
$\mathbf{4}$ & $61-80 \%$ of leaves yellowed and wilted \\
$\mathbf{5}$ & $81-100 \%$ of leaves yellowed and wilted. \\
\hline
\end{tabular}

Source: Sibounnavong et al. (2010)

\section{Result}

Severity of Fusarium wilt in two tomato accessions treated with Acibenzolar-S-methyl (ASM)

Severity of Fusarium wilt in both tomato accessions treated with ASM to Fusarium wilt recorded 4 to 8 Weeks after Transplanting (WAT) is shown in Figure 1. None of the treatments had any statistically significant effects on disease severity at 4 WAT on the two tomato accessions. Tomato plants whose seeds were not primed and seedlings were not treated with ASM (Treatment $\mathrm{Nn}$ ) had significantly higher disease severity of 1.33 at 5 WAT, 2.00 at 6 WAT, 2.17 at 7 WAT and 3.33 at 8 WAT than any other treatment on FUNAABTO 0168 (Accession1). On FUNAABTO 0178, treatment $\mathrm{Nn}$ and $\mathrm{Pn}$ showed high severity with no significant difference between the treatment at 5 WAT, 6 WAT and 7 WAT. Tomato plants whose seeds were not primed and seedlings were not treated with ASM (Treatment $\mathrm{Nn}$ ) had significantly higher disease severity of 1.67 at 8 WAT. Occurrence of symptoms of Fusarium wilt on ASM treated and untreated tomato plant appeared a week after inoculation.

Yield of two tomato accessions treated with Acibenzolar-S-methyl (ASM)

Fruit yield of ASM-treated tomato plants in inoculated soil from Accession I (FUNAABTO 0168) and II (FUNAABTO 0178) at maturity is shown in Figure 2. Tomato plant with primed seeds and sprayed seedlings (Ps) had highest yield of $3.350 \mathrm{t} /$ ha on Accession I and $4.14 \mathrm{t} /$ ha on Accession II while control (untreated tomato plant (Nn)) had least yield of $3.40 \mathrm{t} /$ ha on accession I and $3.57 \mathrm{t} / \mathrm{ha}$ on Accession II.

There was a significant difference at $p<0.05$ in the yield between the two tomato accessions and the treatment that was investigated. 
Table 2: Description and designation of the treatments

\begin{tabular}{lll}
\hline Treatment Description & Designation
\end{tabular}

1

Seeds primed in ASM and seedlings sprayed with ASM after PS transplanting

2

Seeds primed in ASM and seedlings root dipped in ASM before $\mathrm{Pr}$ transplanting

Seeds primed in ASM and seedlings untreated further with ASM Pn during transplanting

4

Seeds not primed in ASM and seedlings sprayed with ASM after NPs transplanting

5

Seeds not primed in ASM and seedlings root-dipped in ASM $\mathrm{Nr}$ before transplanting

6

Seeds not primed in ASM and seedlings not treated further with $\mathrm{Nn}$ (control) ASM during transplanting

Description and designation of the treatments; Field survey, 2014
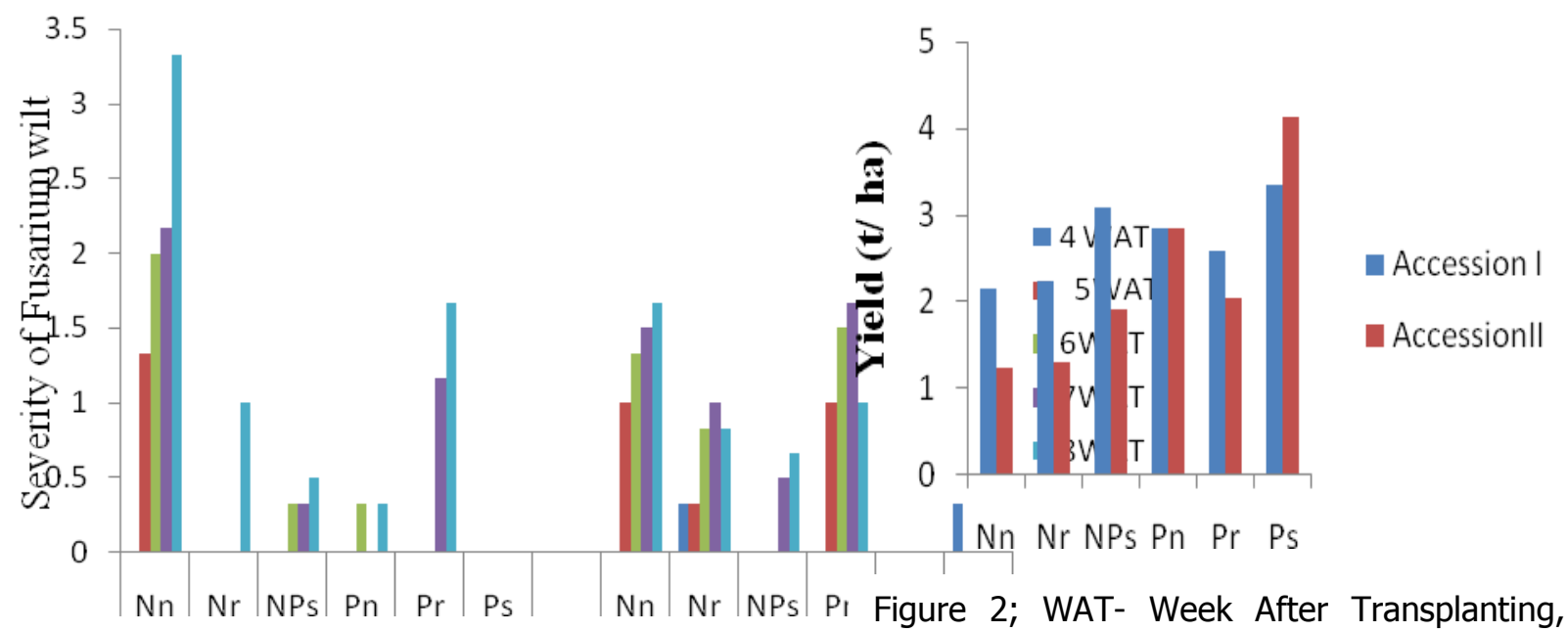

Figure 1; WAT- Week After Transplanting, $\mathrm{Nn}$-untreated tomato plants (control), $\mathrm{Nr}$ Not primed seeds and root dipped seedlings, NPs- Not primed seeds and sprayed seedlings, Pn- Primed seeds and not treated seedlings, Pr- Primed seeds and root dipped seedlings, Ps- Primed seeds and sprayed seed.

Figure 2; WAT- Week After Transplanting, Nnuntreated tomato plants (control), Nr- Not primed seeds and root dipped seedlings, NPs- Not primed seeds and sprayed seedlings, $\mathrm{Pn}$ - Primed seeds and not treated seedlings, Pr- Primed seeds and root dipped seedlings, Ps- Primed seeds and sprayed seed. 


\section{Discussion}

In this study, ASM proved to protect the two treated tomato plants as observed in reduced severity of Fusarium wilt on tomato plants treated with it. Similar observation was reported by other researchers finding ASM very useful in reducing disease severity due to pathogen infection in plant species from different pathogens by activating plant defense mechanisms in plants such as cowpea (Latunde-Dada and Lucas, 2001), cauliflower (Godard et al., 1999), Arabidopsis (Lawton et al., 1996) and tobacco (Cole, 1999). But contrary to the report from Haung et al. (2012) which stated that application of ASM did not significantly reduce disease development or final disease severity of bacterial spot.

In this study, spraying of the tomato seedlings with ASM solution protected the tomato plant against isolate of $F$. oxysporum compared to untreated seedlings. Similar findings are reported in field by Csino et. al. (2001) and Pappu et. al. (2000) in which experiment with foliar sprays of ASM led to reduction in the incidence and severity of tobacco spotted wilt disease.

According to Anfoka (2000), combination of different application methods of ASM should be tried to determine the most reliable and effective methods of ASM application against pathogen. In this study, primed seeds with sprayed seedlings (Ps) showed to be the most effective method of ASM application to Fusarium wilt in the two accessions with least severity of the $F$. oxysporum, also with increased fruit yield. Friedrich et. al. (1996) also applied ASM in tobacco plants and observed that the spray was effective in protecting tobacco plants against pathogen infection. Primed seeds with root-dipping seedlings ( $\mathrm{Pr}$ ) in ASM solution protected both accessions against the pathogen with neither occurrence nor progression in degree of the disease.

In term of fruit yield, tomato plants treated with ASM (regardless of methods of application) had higher yield than untreated plants. Similar observation was made by Galliteli et. al. (1991) who reported that single application ASM to the roots of young tomato plants protected tomato plant against most serious strains of Cucumber Mosaic Virus and reduced yield loss. However, Görlach et al. (1996) did not record reduction in yield of ASM-treated plants. Obradovic et al. (2004) observed that the quantity of marketable fruit harvested from ASM-treated plant was numerically lower but statistically insignificant from the yield harvested from non-ASM treated plants. Also, Louws et. al. (2001) reported statistically non-significant but numerically consistent yield reduction shown in tomato plant treated with ASM, compared to those treated with fungicide.

It therefore appeared that better yield was recorded by workers that compared synthetic fungicides with ASM application. This, however, did not remove the side effects of synthetic fungicides on human and the environment (Ogzonen et. al., 2001). The workers consistently pointed out that the yield in ASM-treated plants, though numerically lower, but were not significantly different from fungicides-treated plants (Louws et. al., 2001; Obradovic et. al., 2004). The environmental consideration in the use of ASM is an additional advantage on the observed higher yield upon ASM application (Oliveira et. al., 2016).

In conclusion, application of Acibenzolar-S-methyl (ASM) was able to induce resistance in the two tomato accessions with low severity of Fusarium oxysporum f. sp lycopercisi. Combine ASM application method can be employ for good result in production of tomato with a definite increase in yield of tomato fruit as observed. ASM can be a useful tool in Integrated Pest Management.

\section{References}

Adenuga, A. H., Muhammad-Lawal, A., and Rotimi O. A. (2013) Economics and Technical Efficiency of Dry Season Tomato Production in Selected Areas in Kwara State, Nigeria. Agris on-line Papers in Economics and Informatics 5 (1): 11-19.

Agrios, G. N. (1997) Plant Pathology. San Diego, CA: Academic Press.

Alscher R. G, Donahue J. L. and Cramer C. L. (1994) Reactive oxygen species and antioxidants: relationships in green cells. Physiol. Plant. 100: 224- 233.

Anfoka, G. H. (2000). Benzo-(1, 2, 3)thiadiazole-7-carbothioic acid $S$ methyl ester induces systemic resistance in tomato (Lycopersicon esculentum. Mill cv. Vollendung) to Cucumber mosaic virus. Crop Prot.19:401405. 
Anang, B. T., Zulkarnain Z. A. and Yusif S. (2013). Production constraints and measures to enhance the competitiveness of the tomato industry in Wenchi municipal District of Ghana. American Journal of Experimental Agriculture 3 (4): 824-838.

Arah, I. K. (2015). "An overview of postharvest challenges facing tomato production in Africa." In Africa: Diversity and Development, 37th AFSAAP Conference Proceedings, AFSAAP.ISBN: 978-0-9924793-8-1.

Ayandiji, A, Adeniyi O. R. and Omidiji, D. (2011) Determinant Post Harvest Losses among Tomato Farmers in Imeko-Afon Local Government Area of Ogun State, Nigeria. Global J. of Sci. Frontier Res. 11 (5):22-28.

Brisson, L. F, Tenhaken, R. and Lamb C. L. (1994). Function of oxidative cross-linking of cell wall structural proteins in plant disease resistance. Plant Cell. 6:1703-1712.

Cole, D. L. (1999). The efficacy of acibenzolarS-methyl, an inducer of systemic acquired resistance against bacterial and fungal diseases of tobacco, Crop Prot. 18: 267- 273.

Csinos, A. S., Pappu, H. R., McPherson, R. M. and Stephenson, M. G. (2001). Management of Tomato spotted wilt virus in flue-cured tobacco with acibenzolar-S-methyl and imidacloprid. Plant Dis. 85: 292-296.

Dangl, J. L., Dietrich, R. A. and Richberg, M. H. (1996). Death don't have no mercy: Cell death programs in plant-microbe interactions. Plant Cell 8: 1793-1807.

Davies, J. M. L. (1982). Verticillium and Fusarium Wilt of Tomato. Ministry of Agriculture, Fishery and Food (Publications), Northumberland NE66 2PF, pp: 6.

Delaney, T., Uknes, S., Vernooij, B., Friedrich, L., Weymann, K., Negmtto, D., Gaftney, T., Gut-Rella, M., Kessmann, H., Ward, E. and Ryals, J. (1994). A central role of salicylic acid in plant disease resistance. Plant Sci. 266: 1247-1250.

Friedrich, L., Lawton, K., Dincher, S., Winter, A., Staub, T., Uknes, S., Kessmann, H. and Ryals, J. (1996). Benzothiadiazole induces systemic acquired resistance in tobacco. Plant J. 10: $61-70$.

Galliteli, D., Vovlas, C., Martelli, G., Montasser, M. S., Tousignant, M. E. and Kaper, J. M. (1991). Satellite-mediated protection of tomato against cucumber mosaic virus: II. Field test under natural epidemic conditions in southern Italy. Plant Dis. 75: 93-95.

Godard, J. P., Ziadi, S., Monot, C. C., Le Corre, C. and Silue, D. (1999) Benzothiadiazole (BTH) induces resistance in cauliflower (Bras- sica oleracea var botrytis) to downy mildew of crucifers caused by Peronospora parasitica, Crop Prot. 18 : 397-405.

Görlach, J., Volrath, S., Knauf-Beiter, G., Hengy, G., Beckhove, U., Kogel, K.-H., Oostendorp, M., Staub, T., Ward, E., Kessmann, H. and Ryals, J. (1996). Benzothiadiazole, a novel class of inducers of systemic acquired resistance, activates gene expression and disease resistance in wheat. Plant Cell 8:629-643

Huang, C. H., Vallad, G. E., Zhang, S., Wen, A., Balogh, B., Figueiredo, J. F. L., Behlau, F., Jones, J. B., Momol, M. T. and Olson, S. M. (2012). Effect of application frequency and reduced rates of acibenzolar-S-methyl on the field efficacy of induced resistance against bacterial spot on tomato. Plant Dis. 96:221227.

Kauss, H. (1987). Some aspects of calciumdependent regulation in plant metabolism. Annual Review Physiol. Plant. 38, 47-72.

Kistler, H. C. (2001). Evolution of host specificity in Fusarium oxysporum. Ame. Phytopath. Soc. pp 70-82.

Kuzniak, E. and Sklodowska, M. (2001). Glutathione and related enzymes in chloroplasts of tomato leaves infected by Botrytiscinerea. Plant Sci. 160: 723-731.

Lamb C. J. and Dixon R. A. (1997). The oxidative burst in plant disease resistance. Ann. Rev. Plant. Physio. Plant Mol. Bio. 48: 251-275.

Latunde-Dada, A. O. and Lucas, J. A. (2001). The plant defence activator acibenzolar-Smethyl primes cowpea [Vignia unguiculata (L.) 
Walp.] seedlings for rapid induction of resistance. Physio. and Mol. Plant Path. 58: 199-208.

Lawton, K., Friedrich, L., Hunt, M., Weymann, K., Staub, T. Kessmann, H. and Ryals, J. (1996). Benzothiadiazole induces disease resistance in Arabidopsis by activation of the systemic acquired resistance signal transduction pathway. Plant J. 10: 71-82.

Leslie, J. F. Summerell, B. A. and Bullock, S. (2006). The Fusarium laboratory manual. Blackwell Publishing Professional.2121, state avenue, Ames, USA.

Louws, F. J., Wilson, M., Campbell, H. L., Cuppels, D. A., Jones, J. B., Shoemaker, P. B., Sahin, F. and Miller, S. A. (2001). Field control of bacterial spot and bacterial speck of tomato using a plant activator. Plant Dis. 85: 481-488

Low, P. S. and Merida, J. R. (1996). The oxidative burst in plant defense: Function and signal transduction. Physio. Plant. 96: 533542.

Nelson, P. E., Toussoun, T. A. and Marasas, W. F. O. (1983). Fusarium species.An Illustrated manual for identification. Pennsylvania: Pennsylvania State University Press. p193.

Nicholson, R. L. and Hammerschmidt, R. (1992). Phenolic compounds and their role in disease resistance. Ann. Rev. Plant Path. 30:369-389.

Obradovic, A., Jones, J. B., Momol, M. T., Balogh, B. and Olson, S. M. (2004). Management of tomato bacterial spot in the field by foliar applications of bacteriophages and SAR inducers. Plant Dis. 88:736-740.

Ogzonen, T. N., Lemanceau, P. and Alabouvette, C. (2001). Biocontrol of fusarium diseases by fluorescent Pseudomonas and non-pathogenic Fusarium. Crop Prot. 10: 279286.

Oliveira, M. D. M., Varanda, C. M. R. and Felix M. R. F. (2016). Induced resistance during the interaction pathogen $x$ plant and the use of resistance inducers. Phytochem. Soc. of Euro. 15: $152-158$.

Pappu, H. R., Csinos, A. S., McPherson, R. M., Jones, D. C. and Stephenson, M. G. (2000).
Effect of acibenzolar-S-methyl and imidaclopridon suppression of tomato spotted wilt Tospovirus in flue-cured tobacco. Crop Prot. 19:349-354.

Popoola A. R., Ercolano, M. R., Kaledzi, P. D., Ferriello, F., Ganiyu, S. A., Dapaah, H. K., Ojo, D. K., Adegbite, D. A., Falana, Y. and Adedibu, O. B. (2012). Molecular and phenotypic screening of tomato genotypes for resistance to Fusarium wilt. Ghana J. of Hort. 10: 61-67.

Ryals, J. A., Neuenschwander, U. H., Willits, M. G., Molina, A., Steiner, H. Y. and Hunt, M. D. (1996). Systemic acquired resistance. Plant Cell. 8: 1809-1819.

Sibounnavong, P., Keoudone, C., Soytong, K., Divina, C. C. and Kalaw S. P. (2010). A new mycofungicide Emericella nidulans against tomato wilt caused by Fusarium oxysporum $f$ sp. lycopersici. J. Agric. Technol. 6 (1): 19-30.

Suárez-Estrella, F., Vargas-Garcia, C., Lopez, M. J., Capel, C. and Moreno J. (2007) Antagonistic activity of bacteria and fungi from horticultural compost against Fusarium oxysporum f. sp. melonis. Crop Prot. 26: 4653.

Tello-Marquina, J. C. and Lacasa, A. (1988). Evolution of races among Fusarium oxysporum f.sp. lycopersici. De Sanidad Vegetal Plagas. 14: 335-341.

Uknes, S., Mauch-Mani, B., Moyer, M., Potter, S., Williams, S., Dincher, S., Chandler, D., Slusarenko, A., Ward, E. and Ryals, J. (1992). Acquired resistance in Arabidopsis. Plant Cell 4: 645-656.

Willcox, J.K., Catignani, G.L. and Lazarus, S. (2003). Tomatoes and cardiovascular health. Critical Rev. in Food Sci. and Nut. 43:1-18.

Wojtaszek, P. (1997). The oxidative burst: a plant's early response against infection, Biochem. J. 322: 681-692. 